\title{
VEIL (NIQÂB) PROBLEMATICS IN ISLAMIC LAW PERSPECTIVE; RELIGION OR CULTURE? (ISLAMIC LEGAL APPROACH)
}

\author{
Mohammad Yusuf Setyawan, Owusu-Ansah David \\ Universitas Islam Negeri Sunan Kalijaga Yogyakarta, Indonesia \\ James Madison University, Harrisonburg, United States \\ mohammadsetyawan22@gmail.com,owusuadx@jimu.edu
}

\author{
Received: 04-03-2021 Revised: 18-06-2021 Accepted: 29-07-2021
}

\begin{abstract}
Abstrak
Fenomena wanita bercadar di Indonesia masib kerap menimbulkan persepsi negatif dari mayoritas masyarakat Indonesia. Dalam beberapa tabun terakbir, media massa juga berulang kali menyoroti polemike terkait pelarangan cadar di beberapa instansi dan even tertentu. Penelitian ini bertujuan untuk mengungkap kedudukan cadar dalam perspektif bukum Islam, apakah merupakan bagian dari ajaran agama yang harus dijaga eksistensinya, ataukah banya budaya masyarakat tertentu yang tidak berlaku untuk semua umat Islam. Pendekatan bukum dalam studi Islam terkait fenomena cadar sangat dibutubkan untuk mengungkap status cadar. Penelitian ini merupakan penelitian kepustakaan dengan menggunakan metode penelitian kualitatif yang bersifat deskriptif. Dari penelitian ini ditemukan bahwa mayoritas abli bukum Islam dan pakar syariat menghukumi bahwa wajah wanita tidak termasuk aurat. Mereka menyandarkan bukum ini pada Al-Qur'an dan sunah. Para ulama juga tidak terlalu mempermasalabkan kedudukan cadar di tengah masyarakat Arab karena cadar memang sudah ada dalam budaya sebagian dari mereka. Cadar masuk dalam kategori mubah, bukan sesuatu yang diperintabkan oleb agama maupun sesuatu yang dilarang agama. Jika wajah wanita bukan aurat maka dalam kondisi-kondisi tertentu terutama dalam saat terdesak, ia sangat diharapkan untuk menampakkan wajahnya. Penelitian terkait cadar dengan pendekatan lain seperti teologi, fenomenologi, kebudayaan, dan lain-lain akan sangat membantu dalam memecabkan problematika cadar di Indonesia.
\end{abstract}

Kata kunci: cadar, bukum Islam, agama, budaya.

\begin{abstract}
The phenomenon of wearing veil (niqâb) by Muslim women in Indonesia leads to negative perspectives frequently by the majority. Recently, mass media has also highlighted polemics related to the prohibition of wearing the veil in certain institutions and events repeatedly. This study aims to reveal the position of wearing niqab in the perspective of Islamic law, whether it is a part of religious dogma that must be maintained, or is it just a certain community's culture that is not an obligation for every Muslim. A legal approach in Islamic studies related to the veil phenomenon is needed to reveal the status of wearing a veil. This kind of research is library research using descriptive qualitative research methods. From this study, it was found that the majority of Islamic jurists and sharia experts decided that a woman's face was not included in the genitals. Their decisions rely on Quran and sunnah as the main sources of Islamic law. The scholars are not really questioning the habituation of wearing the veil in Arab society because it was already being a fashion culture of some people there. In order to
\end{abstract}


Veil (Niqâb) Problematics In Islamic Law Perspective; Religion Or Culture?,..

wear a veil is included in the category of mubah, is not something that is ordered or even prohibited by religion. If a woman's face is not genitals, then under certain conditions, especially when she got pressure, she is expected to show her face. Research related to the law of wearing a veil with other approaches such as theology, phenomenology, culture, etc. will be very helpful in solving the problem of wearing the veil in Indonesia..

Keywords: veil (niqâb), Islamic law, Religion, Culture.

\section{INTRODUCTION}

During the last few years, the problem of wearing veil has emerged as a crucial issue and widely debated in Indonesia. There are several phenomena in society regarding the regulation of wearing veil that have been highlighted by the media in recent times. Among these phenomena are the confusion over the government's policy to ban the veil among the State Civil Servants (ASN), the discourse on banning the veil in a number of universities, and most recently the withdrawal of MTQ participants in North Sumatra from the race because it was not permitted by the jury to keep the veil on her performing ${ }^{1}$.

These various phenomena have quite graced the screen in Indonesia and caused controversy among observers and community leaders. This controversy shows that veil is not yet fully accepted by the people of Indonesia. Some people say that veil is a part of part of religious orders that the existence must be uphold. Meanwhile, some others say that veil is only an Arabian culture and not related to the religious orders. The Islamic legal approach in analyzing the problems of wearing veil will be very helpful in providing solutions to the society ${ }^{2}$.

The law in Arabic literature which used to called shara', has related meaning with Sharia. Sharia are all the rules made by Allah SWT or those that have been made in order to become a human foothold in a relationship with God, relationships with fellow Muslims, or with fellow humans, and their relationship with nature and life. ${ }^{3}$ Meanwhile, the provision shows that the laws include certain rules for mukallaf's action and their condition related to issues and even their face ${ }^{4}$.

\footnotetext{
1 Vivi Sartika dan M. Yusuf, “'Bercadar Itu Pengakuan'; Reproduksi Makna Cadar di Kalangan Pengguna,” Indonesian Journal of Religion and Society 2, no. 2 (18 Desember 2020): 87-96, https://doi.org/10.36256/ijrs.v2i2.107.

${ }^{2}$ Lisa Aisiyah Rasyid dan Rosdalina Bukido, "Problemtika Hukum Cadar Dalamislam: Sebuah Tinjauan Normatif-Historis," Jurnal Ilmiah Al-Syir'ah 16, no. 1 (1 Agustus 2018): 74-92, https://doi.org/10.30984/jis.v16i1.648; Hanif Kistoro dkk., "Islamophobia in education: perceptions on the use of veil/niqab in higher education," Indonesian Journal of Islam and Muslim Societies 10, no. 2 (21 Desember 2020): 227-46, https://doi.org/10.18326/ijims.v10i2.227-246.

${ }^{3}$ Mahmûd Shaltût, al-Islâm Aqîdat wa Sharîa (Cairo: Dâr ashl-Shurûq, 2001), 10.

${ }^{4}$ Irene Zempi, "'It's a part of me, I feel naked without it': choice, agency and identity for Muslim women who wear the niqab," Ethnic and Racial Studies 39, no. 10 (8 Agustus 2016): 1738-54, https://doi.org/10.1080/01419870.2016.1159710; Anna Piela, "How Do Muslim Women Who Wear the Niqab Interact with Others Online? A Case Study of a Profile on a Photo-Sharing Website," New Media \& Society 19, no. 1 (1 Januari 2017): 67-80, https://doi.org/10.1177/1461444816649919; Faegheh Shirazi dan Smeeta Mishra, "Young Muslim Women on the Face Veil (Niqab): A Tool of Resistance in Europe but Rejected in the United States," International Journal of Cultural Studies 13, no. 1 (1 Januari 2010): 43-62, https://doi.org/10.1177/1367877909348538.
} 
Legislation will be called "pure God's law" if the source is from Allah SWT, and legislation will be called "positive law" if the source is from humans, both individuals and groups. Shari'a or God's law are all the regulations that Allah SWT has revealed in the Quran or revealed to the Prophet Muhammad, or the endorsement of existing regulations. In addition, we know another form of law in the form of positive law, namely all the rules made by the mujtabid and their religious leaders as a conclusion from God's legal texts. ${ }^{5}$

Statements or legislation in this paper are the sources or basic laws from God as well as he laws concluded by the mujtahid consisting of figh scholars whose conclusions rests on the main sources of law from God. There are four main arguments on which the Islamic scholars rely on their conclusion of the law and the ijtihad, namely Quran, sunnah, ijma, and qiyas ${ }^{6}$.

Quran, which is the word of Allah SWT which was revealed to the Prophet Muhammad with clear Arabic, as an explanation for the goodness of humans in their life in this world and the hereafter. ${ }^{7}$ Quran is the most important basis for the Shari'a and is not debated by Muslims. Most of the Shari'a laws have been covered by the Quran generally so it requires a sunnah to explain the general arguments in the Quran. The second argument after the Quran is sunnah. Sunnah, which is something that was narrated from the Prophet Muhammad which includes his words, his deeds and his silence are followed by his companions. The position of the sunnah is as a detailed explanation regarding general law in the Quran, as a legal limitation that is conveyed absolutely in the Quran, and as a specific law that is general in the Quran'.

Apart from Quran and hadith, the evidence in the conclusion of law is also obtained through ijma and qiyas. Ijma, namely the agreement of all mujtahid fiqh from among moslims in a certain century on the reality of law or an issue. 'The majority of scholars agree that ijmak is one of the sources of syariah and consider it a compulsory shari'a argument. Meanwhile, qiyas (analogy) means following a branch law to the law of origin of the case because it has the same illat (cause) of law. Kias is needed because the Shari'a texts in the Quran and the sunnah are limited when compared to the various problems that arise over time. Apart from these four arguments there are still many other arguments used by the mujtahid such as opinion (alra'y), istibsân, mașâlih mursalât, and others.

The period of the formation of Islamic syariah has been four phases. The first phase is the prophetic era which lasts 22 years plus several months. According to the commentators, there are no more verses regarding sharia laws that came down after the word of Allah (see Surah al-Maidah verse 3). In the Mecca phase, practical laws have not become the attention

\footnotetext{
5 'Abd 'l-Wahhâb Khalâf, Khulâșah at-Tashrî' 'l-Islâmî (Kuwait: Dâr 'l-Qalam, t.t.), 7.

6 Abdurrahman Hakim, "Cadar Dan Radikalisme Tinjauan Konsep Islam Radikal Yusuf Qardhawi," Ijtimaiyya: Jurnal Pengembangan Masyarakat Islam 13, no. 1 (11 Juli 2020): 103-16, https://doi.org/10.24042/ijpmi.v13i1.5808.

7 ‘Alî Ḥasbullâh, Ușul at-Tashri’ 'l-Islâmî (Cairo: Dâr 'l-Ma'ârif, 1976), 25.

8 Alireza Korangy dkk., Essays in Islamic Philology, History, and Philosophy (Walter de Gruyter GmbH \& Co KG, 2016); M. Quraish Shihab, "Membumikan Al-Quran," Bandung: Mizan, 1992, http:/ / saifbintoro.mywapblog.com/files/membumikan-al-quran.pdf.

${ }^{9}$ Muḥammad Yûsuf Mûsa, at-Tashrî' 'l-Islâmî wa Atharuh fî̀ 'l-Fiqh 'l-Gharbî̀ (Beirut: al-'Ashr 'l-Hadith, 1991), 26.
} 
and purpose of the Sharia because Muslims have not made it possible to form a society based on Islamic law. The Mecca phase is marked by an emphasis on theology (creed).

Then in the Medina phase, practical laws regarding marriage requirements, divorce, inheritance, hudud law, sale and purchase, debts, war orders, and laws governing relations between Muslims and non-Muslims will come down. The initiation in this phase is clearly based on the revelation that was sent to the Prophet and also his explanation regarding these revelations. As the messenger of Allah SWT, The Prophet independent in the delivery of sharia without intervention from friends even though they have the right to ask questions and confirm understanding.

The next phase is the era of the companions, which began since the death of the Prophet, until the end of the 1st century A.D. The formation of sharia at this time was based on the interpretation and ijtihad of senior friends regarding religious laws that were not mentioned in the Quran and the sunnah clearly. The fatwas and religious views of these companions are a source of interpretation of the legal texts in the Quran and the sunnah. The prominent mujtahids among the companions were the four Khulafâ ar-Râsyidîn plus Zaid bin Thabit in Medina, Abdullah bin Abbas in Makkah, Abdullah bin Mas'ud in Iraq, and Abdullah bin Amr bin al-Ash in Egypt. ${ }^{10}$

After the era of friends, the ijtihad or codification phase began to emerge. The era of ijtihad began at the beginning of the 2nd century $\mathrm{H}$ until the middle of the 4th century A.D. This era was marked by rampant writing and codification by scholars in all fields of science. The Sunnah of the Prophet. and ijtihad friends and tabiin began to be codified. The jurisprudence and ushul figh also caught the attention of scholars, giving birth to four wellknown fiqh schools: the Hanafi school, the Maliki school, the Shafii school, and the Hambali school. This Ijtihad may only be carried out by faqîh and mufti who meet the proper requirements to do so. From here, the diversity of opinions emerged and had a major influence on the development of jurisprudence ${ }^{11}$.

It did not last long, the ijtihad phase ended and Muslims entered the imitation phase. This era is different from the previous era because the ijtihad of the ulama has decreased in interacting with the sources of sharia. They rely on experts and the results of ijtihad from the priests of the previous schools. Therefore, the scholars and shari'a experts agreed to close the door of ijtihad and chose to be guided by the opinion of the mazhab imams while limiting muftis in giving fatwas from their own discoveries. This brief description of Islamic law becomes an opening in examining the position of the veil from the perspective of Islamic law, whether the veil is part of religious orders or is it just a certain society's culture.

${ }^{10}$ Khalâf, Khulâșah at-Tashrì" 'Islâmî, 33.

11 Irene Zempi, "Veiled Muslim women's views on law banning the wearing of the niqab (face veil) in public," Ethnic and Racial Studies 42, no. 15 (18 November 2019): 2585-2602, https://doi.org/10.1080/01419870.2019.1588985. 


\section{RESEARCH METHOD}

In accordance with the problems studied, this is a library based research. It uses qualitative methods that are descriptive. Qualitative research is research that seeks to reveal the various uniqueness contained in individuals, groups, communities, or organizations in daily life in a comprehensive, detailed, deep, and scientifically accountable manner. Descriptive is research that aims to explain something as it is in depth. The data collected are in the form of words, pictures, and not numbers.

Basically, qualitative research is carried out to formulate theories, not to test theories. Or in other words, this qualitative research is to find new knowledge, or formulate new theories based on the data collected. This qualitative research also has the character of explaining a problem, namely the problem under study. ${ }^{12}$ In this research, the material object is the veil and the formal object is the Islamic legal approach. This study begins with a brief explanation of the legal approach in Islamic studies followed by an analysis of the position of the veil using a review of Islamic law. Specifically, this research will also answer which elements are more dominant to be pinned on the veil, whether religious or cultural elements.

The approach used in analyzing material objects in this study is the Islamic legal approach which aims to reveal the position of the veil in Islam, whether it is part of religious orders or is it just a certain culture of society. In his analysis, the author will include the opinions of scholars from four well-known fiqh schools, namely the Hanafi School, the Maliki School, the Hanbali School, and the Hanbali School. The term approach according to language is often referred to as madkhal (Arabic) or pendekatan (Indonesian). Approach can be interpreted as a person's perspective to understand something. If the object is Islam, the approach in question is the person's perspective on understanding Islam itself.

In understanding the Quran and hadith, an appropriate, accurate, and responsive approach to understand Islam is needed. Thus, it is hoped that Islam will be a teaching system that can be understood comprehensively. ${ }^{13}$ The legal approach can be said to be quite dominant besides the textual and contextual approaches. Jurisprudence or Islamic law is one of the most recognized fields of Islamic studies by the public. This is partly because jurisprudence is directly related to people's lives. From birth to death, humans are always connected with figh. Figh science is a group of laws concerning human deeds which are taken from detailed arguments. Sharia is different from fiqh. Sharia is based on the text of the Quran or sunnah directly, without having necessary for giving a reason, while fiqh is based on arguments developed by scholars through reasoning or ijtihad while still adhering to the spirit contained in sharia. ${ }^{14}$

Sources and data were obtained from various literatures that have a correlation with the problem under study, either in the form of books, scientific journals, or various information through the mass media. Most of the jurisprudence opinions in this study were

12 Abdul Chaer, Kajian Bahasa: Struktur Internal, Pemakaian, dan Pemelajaran, Cet. 1 (Jakarta: Rineka Cipta, 2007), 11.

13 Dede Ahmad Ghazali dan Heri Gunawan, Studi Islam: Suatu Pengantar dengan Pendekatan Interdisipliner (Bandung: Rosda Karya, 2017), 64.

${ }^{14}$ Abuddin Nata, Metodologi Studi Islam (Jakarta: RajaGrafindo Persada, 2008), 298. 
taken from contemporary Arabic books. This is done to minimize the possibility of errors in the Indonesian translation. In addition, references to Islamic law and the veil are numerous and varied in Arabic books. Meanwhile, references to the concept of an approach to Islamic studies are taken from Indonesian language books written by competent Muslim scholars.

\section{DISCUSSION}

\section{LEGAL APPROACH IN ISLAMIC STUDIES}

Ethymologically, Islamic law consists of two words, namely law and Islam. Law (alhụkm) in Al-Munawir dictionary means decision and power. Meanwhile, Islam (al-Islâm) means surrender and safety. In terminology, Islamic law is a system of rules based on the revelations of Allah SWT. and the Prophet's Sunnah regarding the recognized and believed behavior of the mukalaf, which is binding for all adherents. ${ }^{15}$ Discussions related to Islamic law are included in the realm of the jurisprudence's discipline (fiqh).

Figh is an important science in Islam, it is even a part of the pillars of religion (îmân, Islam, ihsân), which is the scientific part of the derivative of the Islamic concept. When using the fiqh approach in the methodology of Islamic studies, you will find several opinions that are different from one another, that is the concept of the school thought which then develops until the end of time. In the flow of the fiqh approach, the object of Islamic study is directly discussed in the jurisprudence school which was previously studied using principles of Islamic jurisprudence (usul fiqh) which source from fiqh globally. ${ }^{16}$ Fiqh and usûl fiqh are the guidelines for studying Islamic laws.

The legal approach in Islamic studies can be interpreted as an effort to study Islam through a collection of shara' laws, both in the form of divine law purely and positive law produced by imams and mujtahids through their ijtihad. These shara' laws include compulsory (wajib), sunnah, mubah, makruh, and haram. In addition, fiqh requires a scientific instrument called ushul figh which includes rules for formulating syara' laws and their arguments. The main difference between fiqh and ushul figh is that fiqh deals with the knowledge of detailed rules in Islamic law in its various branches, and ushul figh deals with the methods applied in implementing these rules from their source. ${ }^{17}$

In the historical development of Muslims, the period of ijtihad born in some schools of figh as mentioned above. Of all the existing schools, it can be said that there are four schools that are most widely adhered to and maintained until now.

\section{The Hanafi School}

This school was founded by Imam Abu Hanifah who was born in Kufa in 700 AD. In his legal thoughts, Abu Hanifah was influenced by legal developments that occurred in Kufa. Kufa is located far from Medina which is the source of the hadith. Kufa was more develop in social life than Medina, so the problems that arose were even more

\footnotetext{
15 Imam Khoirul Ulumuddin, "Niqab (Cadar) Dalam Perspektif Hukum Islam,” t.t., 98.

16 Asep Maulana Rohimat, Metodologi Studi Islam: Memahami Islam Rabmatan Lil'alamin (Yogyakarta: Gerbang Media Aksara, 2018), 43-45.

17 Zakiyuddin Baidhawy, Islamic Studies: Pendekatan dan Metode (Yogyakarta: Insan Madani, 2011), 196.
} 
complex. Therefore Imam Abu Hanifah used "opinion" or ar-ra'y, qiyas, and istibsân ${ }^{18}$ as the kind of analogy. Abu Hanifah was very careful about the use of the Sunnah and tried his best to make up for it with the Sunnah which was believed its originality.

\section{The Maliki School}

This school led by Imam Malik bin Anas who was born in Medina in 713 AD. The position of Medina as the center of the hadith made him rely on his legal opinions based on the Prophet's sunnah and the companion's sunnah. When he found differences, he will stuck to the traditions of the people of Medina because they come from companion and the traditions of companion are worthy of being a law sources. Apart from the Qur'an and the sunnah, Malik used qiyas and masâlib mursalât. ${ }^{19}$

\section{The Shafii School}

Imam Muhammad bin Idris al-Syafii was born in Gaza in 767 AD. He spent his childhood in Mecca And then when he was teenager, he studied with Imam Malik in Medina. Imam Shafi then lived in Baghdad and studied related to the Hanafi School. In his legal thought, Imam Syafii used the Qur'an, sunnah, ijma, the opinion of some companions which has been confirmed that there was no debating inside it, and qiyas. He referred to many hadiths and rejected the istibsan of Abu Hanifah and mașalih mursalat of Malik. Imam Syafii was the first Islamic jurist who compile usûl figh and the explanation of the basic Islamic law in Islam which contained in al-Risâlat.

\section{The Hambali School}

Imam Ahmad bin Hambal was born in Baghdad in 780 AD. His education was started by studying hadith and then moving to study law. He studied with Imam Syafii until finally he became a teacher. In his legal thought, Ahmad used Quran, sunnah, the opinion of companionsn which was not denied by other companions or the opinion of one or several companions which in line with Quran, sunnah, mursal hadith and qiyas under compulsion. ${ }^{20}$

Apart from the four schools above, there are still many other schools, it's just that not all of them can be known about the basics and methods of extracting the law they use. Among the other founders of the figh school were al-Hasan al-Basri, Abdul Rahman al-Auza'i, Sufyan alTsauri, al-Laits bin Sa'ad, Sufyan bin Uyainah, Daud al-Zhahiri, Ishaq bin Rahawaih, and Abu Tsaur al-Baghdadi. ${ }^{21}$

${ }^{18}$ Istihsân is to determine the law not on a clear level but on an unclear one, because maslahat wants it to be.Harun Nasution, Islam Ditinjau dari Berbagai Aspeknya. Jilid II: ..., Cet. 6 (Jakarta: Penerbit Universitas Indonesia, 1986), 22.

${ }^{19}$ Mașlahat mursalat or mutlaqat is a maslahat that is not mentioned in law. Nasution, 23.

${ }^{20}$ Nasution, 7-12.

21 Atang Abd Hakim dan Jaih Mubarok, Metodologi Studi Islam (Bandung, Indonesia: Remaja Rosdakarya, 2012), 160-61. 


\section{POSITION OF WOMEN'S VEIL AND GENITALS BASED ON ISLAMIC LAW PERSPECTIVE}

According to the Big Indonesian Dictionary (KBBI), veil is a cloth that covers the entire body including the head and face, except for the eyes, commonly worn by Muslim women. The term veil comes from the Persian chador which means a tent. In Iranian tradition, the veil is a garment that covers a woman's entire limb from head to toe. The people of India, Pakistan and Bangladesh call it purdah. Meanwhile, the Bedouins in Egypt and the Arab Gulf call it the burqa. In Arabic, the veil is called the niqab. In Lisân 'l-Arab, the veil means a cloth which covering the woman's face except their eyes. ${ }^{22}$

The discussion of the veil in the religious perception is closely related to the limitations of women's genitals. The majority of jurists said that a woman's face is not a part of the genitals that must be covered. As long as a woman dress properly, and does not showing their body shape and their limbs except their faces and palms of her hands, they have been dressed well according to the guidance of the Shari'a. Women also have the right to wear colorful clothes as long as it is not excessively then become a center of attention. Among the arguments that strengthen this is the word of Allah SWT .:

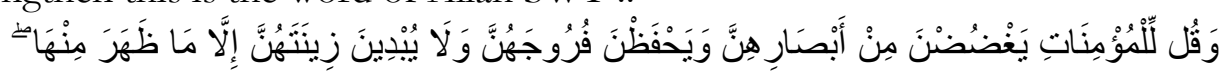

(31) And tell the believing women to reduce [some] of their vision and guard their private parts and not expose their adornment except that which [necessarily] appears thereof. (al-Nur: 31)

The majority of jurists gave the opinion that what is meant by "except that which [necessarily] appears thereof", there are face and the palms of the hands. ${ }^{23}$ They are prohibited from showing the jewelery except what is usually seen from him. Eye liner is facial jewelry and rings are palm jewelry. This interpretation is taken from the majority of companions and tabiin. The majority of jurisprudents also adhere to the following verse pieces:

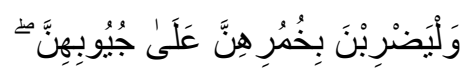

\section{(31) and to wrap [a portion of] their headcovers over their chests. (al-Nur: 31)}

Allah SWT. ordered a Muslim woman to cover her veil over her chest. If the face is obliged to be covered, then of course it has been mentioned in this verse. This verse only commands to cover the neck and chest without covering the face. Scholars such as Imam Nawawi, al-Auza'i, Abu Tsaur, Abu Hanifah, al-Tsauri, and Ahmad mentioned that a woman's face is not aurat. Some scholars said that a woman's face is not kind of genitals according to the four priests of the school or other priests. This agreement is also confirmed by the words of the figures of interpretation, hadith, and figh who have reached the degree of consent. ${ }^{24}$

Judging from the hadith text, in the hadith narrated by Aisyah Ra. mentioned:

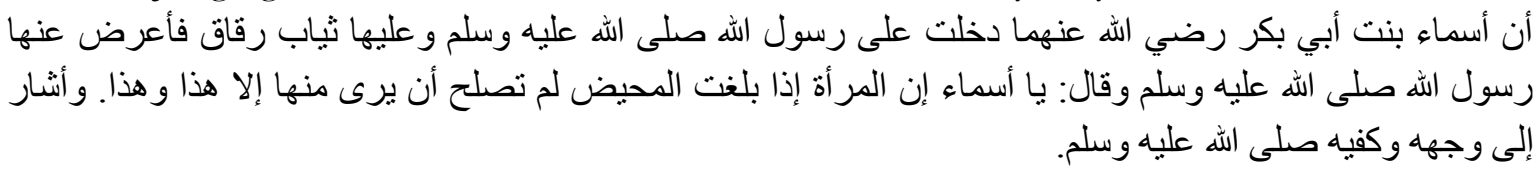

22 Muh Sudirman, “Cadar Bagi Wanita Muslimah dalam Perspektif Hukum Islam” 4 (2018): 56.

${ }_{23}$ Maḥmûd Zaqzûq, an-Niqâb Âdat wa Laisa Ibâdat: ar-Ra'y ash-Shar'î fî̀ an-Niqâb bi Aqlâm Kibâr 'l-Ulamâ (Cairo: Wazârat 'l-Auqâf 'l-Mișriyyat, 2008), 13.

${ }^{24}$ Abd 'l-Halim Abu Shuqqat, Tahrîr 'l-Mar'at fì Ashr al-Risâlat, vol. 4 (Kuwait: Dâr 'l-Qalam, 1995), 174. 
That Asma bint Abu Baker entered to see Rasulullah Saw with thin clothes, then Rasulullah Saw turned away from him and said, "O Asma actually if a woman has reached the age of menstruation (puberty) then there is nothing worth seeing except this and this, while he pointing at his face and palms. (H.R. Abu Daud) In the hadith of Ibn Umar Ra. mentioned that Rasulullah Saw. said:

$$
\text { ولا تنتقب المر أة المحرمة ولا تلبس القفازين. }
$$

Women who take ibram are not allowed to wear the veil and wear gloves. (H.R. al-Bukhari)

This hadith shows that if the face and palms are classified as genitals, then it cannot be prohibited.

Ibn Abbas Ra. narrated:

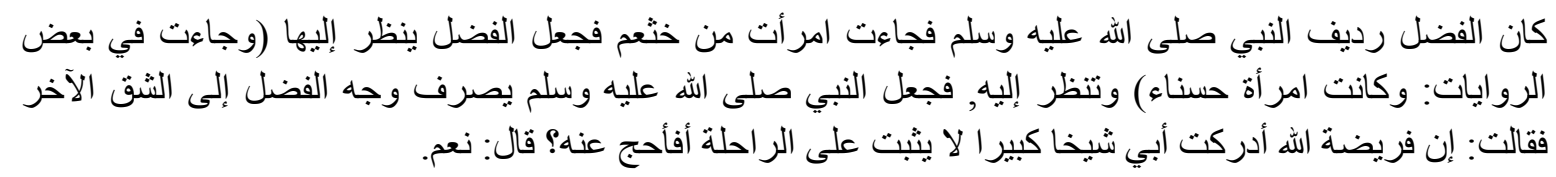

Fadl followed behind the Prophet. then came a woman from the Kabilah Khats'am. Fadl saw the woman (in some of the narrations it is said: the woman was beautiful) and the woman also saw Fadl. Then the Prophet (saw). turned Fadl's face to the other direction. The woman asked: The obligation of Haij has come to my father who is very old and he is not strong enough to travel, can I do Haij for him? Prophet SAW. answer: Yes.

This hadith was narrated by al-Bukhari, Muslim, Abu Daud, and al-Tirmidhi. This incident occurred during the Hajj Wadâ, if the face is classified as genitals, it is certain that it must be covered, but Rasulullah Saw. did not blame the woman who shows her face in front of many people. He doesn't tell a woman to cover her face. On the other hand, if the woman covers her face, then it is certain that Ibn Abbas cannot know whether a woman is beautiful or not. In Ahmad's narration in his musnad, Fadl narrated himself: "I also saw it and the Prophet looked, then he turned my face away from the woman's face, he did it three times and I didn't stop." ${ }^{25}$

In the history of Jabir bin Abdillah Ra. mentioned that the Prophet SAW is reminding women to give alms to avoid hell. Then a black-cheeked woman stood up and asked: Why, O Messenger of Allah? And so on. This narration shows that the woman showed her face. In human interaction, the significant neccessary for humans to show their face in buying and selling transactions and showing palms when giving and receiving.

From the perspective of the four imams of the mazhab, there was an opinion from Imam Abu Hanifah which allows a woman to show her feet because it falls into the category of "(ordinary) appears from it" in the verse above. Ibn Maudud al-Mushili from the Hanafi school said that the feet are not genitals because women need to walk so that the feet will be visible. Moreover, lust is more likely to see the face and palms of the hands so that the feet do not have to be covered. However, there is a history from this school that the feet are included in the genitals outside of prayer.

According to the Maliki school, a woman's genitals include all members of the body except for the face and the palms of the hands. Imam Ibn Khalaf al-Baji said that the scholars

${ }^{25}$ Muhammad al-Ghazâlî, 100 Pertanyaan Tentang Islam, vol. 2 (Cairo: Pusat Terjemah Al-Azhar, 2018), 183. 
of this school agreed that women should not pray wearing a veil so that it was concluded that the face was not aurat. Sheikh al-Shawi said that it was permissible to see his face and palms on the condition that he was without lust. The question is, if this happens, are women obliged to cover their faces and palms? The most popular opinion is that it is not obligatory to close it down, but it is men who are obliged to lower the gaze. Even Malikiyah scholars argue that the veil is punished by heresy and should not be worn by women unless the society where she lives is accustomed to wearing it. This was explained by Sheikh al-Dusuqi.

According to the Shafii school, a woman's face and palms are not included in the genitals. The prohibition of the prophet Muhammad regarding the woman who doing ihram are not allowed to wear a veil and also gloves to proof that their faces and palms are not include into genitals. This school added that the sole of the lower foot (base) does not include into genitals as explained by Imam Nawawi. Wearing veil according to Syafiiah scholars are not mandatory and there was opinion that obliges it outside of prayer, but what is muktamad is the veil is not an obligatory. ${ }^{26}$ Some scholars from the Syafii school said that the entire body of a woman is aurat as said by the Prophet:

$$
\text { المر أة عورة }
$$

Women are genitals. (H.R. al-Tirmidzi)

It's just that there are rukhsahs to reveal the face and palms of his hands because it would be burdensome if the two members had to be closed. In the thought of Hambali school, Ibn Qudamah argued that women may pray with their faces open so that the face is not genitals. Meanwhile, some jurisprudence experts say that all members of a woman's body are genitals including her nails by leaning on Imam Ahmad bin Hambal's history. ${ }^{27}$

Actually how to dress are depends on the culture and tradition of each community. The strongest opinion is the opinion of scholars majority regarding the permission to show the face and palms of the hands for women. People in a country that is more compatible with one of the opinions of the Hambali school, therefore it is fine to wear veil which in line with their traditions. ${ }^{28}$ This is what we see in the Gulf Arab countries. Definetely, this phenomenon is also not related to religion but it is related to the habit of the community which covers women's faces and palms. In Indonesia itself, the phenomenon of veiled women looks strange and sometimes creates negative perceptions in society.

Some people think that the veil is worn on the face so that a woman is completely invisible, this is a refuted claim. Shaykh Muhammad al-Ghazali has read about 12 traditions from the most valid Sunnah books which explained that women showed their faces and palms to the Prophet and he did not ask them to close their two limbs. Likewise, what was done by the companions were in line absolutely with the Prophet's behaviour.

Those who support the obligation of the ordinary veil rely on their opinion to follow the Ummabat 'l-Mukminin (the wives of the Prophet SAW). However, if that condition was true, why Rasullullah and the companions let the woman in that era did not wear veil as

\footnotetext{
${ }^{26}$ Shauqî 'Allâm, Fatâwâ ash-Shabâb (Kairo: Dâr 'l-Iftâ 'l-Mișriyyat, 2019), 240.

${ }^{27}$ Zaqzûq, an-Niqâb Âdat wa Laisa Ibâdat: ar-Ra'y ash-Shar'î fî̀ an-Niqâb bi Aqlâm Kibâr 'l-Ulamâ, 25-30.

28 'Alî Jumu'at, Fatâwâ an-Nisâ: Fatâwâ wa Abkâm li al-Mar'at al-Muslimat (Cairo: Dâr 'l-Muqatțam, 2017), 418.
} 
written in the hadith? Rasulullah has his own special laws regarding his household as Allah's command:

(32) O wives of the Prophet, you are not like anyone among women. (al-Ahzab: 32)

Among these special laws are the prohibitions of the Prophet's wives to marry after the Prophet's death, the multiplication of rewards and sanctions against them, and the removal of the veil for them when interacting with a man. This is understandable considering the prophet's house was visited by many people to ask question regarding religious issues as well as visited by many menssengers from various regions. In addition, The Bedouin Arabs are quite presumptuous in speaking and looking at their dialog patners. This also does not rule out that they was contaminated by Jahiliah traditions in seeing woman. ${ }^{29}$

However, Allah SWT gave exception for some people to meet the Prophet's wives without hijab as He says:

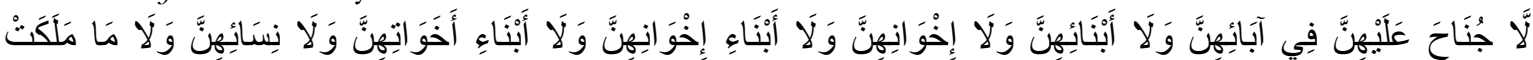

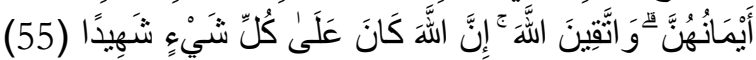

(55) There is no blame upon them [i.e., women] concerning their fathers or their sons or their brothers or their brothers' sons or their sisters' sons or their women or those their right hands possess [i.e., slaves]. And fear Allah. Indeed Alläh is ever, over all things, Witness. (al-Ahzab: 55)

It seems clear in the context of this verse that this regulation was only intended for the wives of the Prophet. This condition due to the verses regarding wearing bijab, women were showing their faces on many occasions, as in mosques, markets, and other public places. Moreover, women also participated in the Hunain War. In this regard, it can conclude that the position of the veil as a cultural costum is more dominant than veil as a religious orders.

Many people think that the veil comes from the Arab culture, but that is not entirely true. Muhammad Quraish Shibab said that the veil did not come from the Arab culture. According to Hasan al-Audah, the Arabs long before Islam came to imitate the Persians who embraced Zoroastrian teachings. They thought that women were not holy creatures therefore they have to cover their mouths and noses so that their breath would not litter their holy fire as their utility for worship..$^{30}$

Next, there are interesting facts about the veil in the hadith of the Prophet regarding the prohibition of wearing veil when doing ihram. In doing ihram, the Prophet prohibited men to wear headgears, trousers, and shoes. Meanwhile, he also prohibited woman to wear a veil and gloves when doing ihram. From this, it can be concluded that the veil is classified as jewelry or accessories for women. It should also be noted that this hadith is the only hadith in which Rasulullah Saw. mentioning the word niqab (veil). This information was mentioned by Abdul Halim Abu Syuqqah in his book Tabrîr 'l-Mar'at fi 'Asr ar-Risâlat.

The proof that the veil is classified as a jewelry or accessories which can be covering a face while other's people will focus only to their eyes. The eyes of a woman who is veiled

\footnotetext{
${ }^{29}$ al-Ghazâlî, 100 Pertanyaan Tentang Islam, 2:810.

30 Abdul Karim Syeikh, "Pemakaian Cadar dalam Perspektif Mufassirin dan Fuqaha" 16, no. 1 (2019): 48-
} 50. 
tend to look more beautiful than when she shows her face wholly, especially if the woman is wearing eyeliner. Eye liner is kind of make up for eyes which was commonly used in Prophet's era. Eventually, in making up way not only by showing off but also by covering face. In addition, for men showing hairstyle is part of make up. On the other hand, wearing a hat, cap, or others head covering is also part of fashion or making self up. This also applies to women, Whether showing the face or covering it can be categorized as a fashion or making self up. ${ }^{31}$

The position of veil as a fashion is closely related to the traditions of the society and it has absolutely nothing to do with religious orders. A woman wearing veil is analogous to wear a ring. This condition is neither ordered nor prohibited by Prophet Muhammad except when doing ihram. The veil was used by some women in the era of Jahiliah, therefore Islam came and did not address this issue. In the history, there was an interesting custom when women who used to wear the veil can decide to remove their veil during their condolence situation due to the death of their husband or family members.

In a hadith it is mentioned:

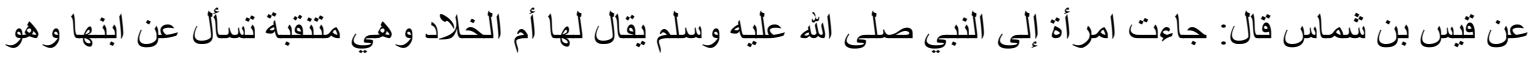

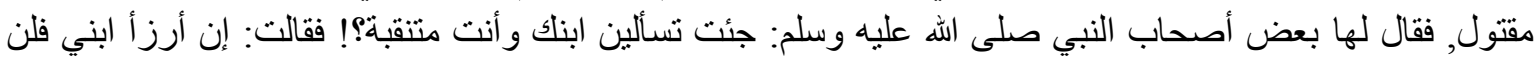

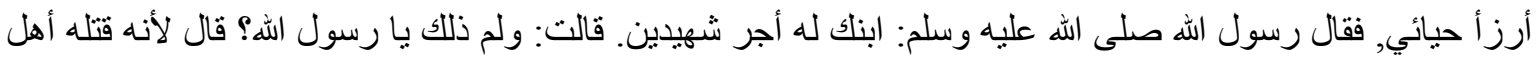

From Qais bin Syammas, he said: A woman who was called Umm al-Khalad came to the Messenger of Allah. veiled to ask about his son who was killed. Then some of the Prophet's companions. said to the woman: You came to ask about your veiled son? The woman answered: If my child is hit by a disaster, my shame will not be affected by the disaster. Then Rasulullah Saw. said: Your son gets the reward of two martyrs. The woman asked: Why is that, O Messenger of Allah? He replied: Because he was killed by the People of the Book. (H.R. Abu Daud).

This hadith shows that the companions were amazed with Umm al Khalad who wearing veil when she was in condolence situation. This condition was interfered with their habituation. In the same time this condition also showed that in certain conditions, woman who used to wear a veil can decided to remove their veil. The arrival of Umm al-Khalad, who was veiled in her condoence, seemed strange to the people around her. This is based on his shame as reflected in his words. His habit of veiling might embarrass him if he takes it off one day. This is another indication that the Prophet SAW. neither commanded nor prohibited women from wearing the veil. Scholars from among the Hambali school such as Abu alQasim al-Kharqi, al-Qadhi Abu Ya'la, and Ibn Qudamah argued that woman should not wear a veil in condolence situation. ${ }^{32}$ This is understandable because women are not so obsessed with making theirself up in their condolence situation, therefore they took off their veils.

Apart from the condolence situation, women will also remove their veils when they want to introduce their identity as was done by Hind binti Utbah who removed her veil in front of the Prophet when she was pledging due to Islam.

عن عبد الله بن الزبير رضي الله عنهما قال: لما كان يوم الفتح أسلمت هند بنت عنبة و النساء معها, و أتين رسول الله صلى الله عليه وسلم و هو بالأبطح فبايعنه. فتكلمت هند فقالت: يا رسول الله, الحمد لله الذي أظهر الدين الذئ الذي اختاره

31 Abû Shuqqat, Tahrîr 'l-Mar'at fì Ashr al-Risâlat, 4:220-21.

32 Zaqzûq, an-Niqâb Âdat wa Laisa Ibâdat: ar-Ra'y ash-Shar'î fî an-Niqâb bi Aqlâm Kibâr 'l-Ulamâ, 46-47. 


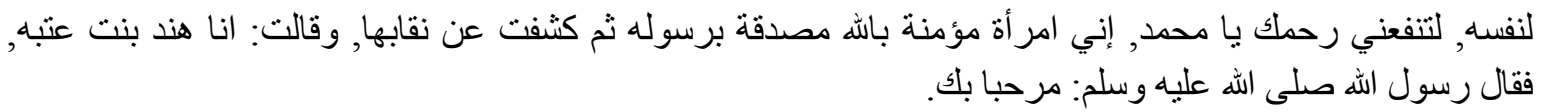

From Abdullah bin al-Zubair Ra., He said: On the day of the Conquest of Mecca, Hind bint Utbah and the women who were with him converted to Islam. They came to the Prophet Mubammad. who was near the water channel to take an assault. Hind spoke: O Messenger of Allah, all praise be to Allah for helping the religion $\mathrm{He}$ has chosen, that you will benefit me from your love, O Mubammad, I am a woman who believes in Allah and justifies His Messenger. Then she took off the veil that covered her face and said: I am Hind bint Utbah. Then Rasulullab Saw. said: Welcome to you. (Narrated by Ibn Sa'ad in his Thabaqat).

Pulled into the current condition of Indonesian society, wearing veil is still relatively strange for Indonesian people which has different cultures from Middle East. In fact, occasionally there is a negative assumption that wearing a veil is a kind of terrorism symbol eventhough that assumption is not entirely true. A wise attitude is highly needed in religion and social life. Do not let good wishes cause unrest and controversy in the community. As a good social being, a person is required to be able to work together and create the general benefit which has a positive impact to theirselves and others.

\section{CONCLUSION}

Based on the majority of Islamic jurist and sharia expert's view, the woman's face is not include as a genitals. Their decision and consideration are rely on the Quran and sunnah. The scholars are not really questioning about the habituation of wearing veil in Arab's society because it was already being a fashion culture of some people there. The veil is included in the category of mubah, in order to wear a veil is not something that ordered or prohibited by religion. Under normal conditions, women are free to choose whether to be veiled or not. The legal review of this veil by Islamic jurists also cannot be separated from other reviews, such as textual, contextual, historical, and others. Regarding the explanation above, the polemic of wearing veil in Indonesia should not be a problems. Wearing veil seems strange in Indonesia, therefore it would be wiser if women were not veiled.

If a woman's face is not genitals, then under certain conditions, especially when she got pressure, she is expected to show her face. These conditions can be in the context of taking exams, competitions, or when entering areas with special rules such as in airports. Banning the veil on campus or public institution such as for civil servant is also a local authority that requires members to follow applicable rules as a form of professional cooperation. A dress code of ethics in an institution must exist and be understood by all its members. Thus, a person who feels that he is not ready to follow the applicable rules in a particular institution or event has the right to resign properly. Therefore, it requires tolerance and cooperation between an institution and also women who are veiled so that each party can tolerate each other. 
Veil (Niqâab) Problematics In Islamic Law Perspective; Religion Or Culture?,..

\section{REFERENCES}

Abu Syuqqah, Abdul Halim. Tabrîr 'l-Mar'at fì Ashr al-Risâlat. Vol. 4. Kuwait: Dar al-Qalam, 1995.

Allam, Shawki. Fatâwâ aș-Shabâb. Kairo: Dar al-Ifta al-Mishriyah, 2019.

Baidhawy, Zakiyuddin. Islamic Studies: Pendekatan dan Metode. Yogyakarta: Insan Madani, 2011.

Chaer, Abdul. Kajian bahasa: struktur internal, pemakaian, dan pemelajaran. Cet. 1. Jakarta: Rineka Cipta, 2007.

Ghazali, Dede Ahmad, dan Heri Gunawan. Studi Islam: Suatu Pengantar dengan Pendekatan Interdisipliner. Bandung: Rosda Karya, 2017.

Ghazali, Muhammad al-. 100 Pertanyaan Tentang Islam. Vol. 2. Kairo: Pusat Terjemah Al-Azhar, 2018.

Gomaa, Ali. Fatâwâ an-Nisâ: Fatâwâ wa Abkâm li al-Mar'at al-Muslimat. Kairo: Dar alMuqhatham, 2017.

Hakim, Abdurrahman. "Cadar Dan Radikalisme Tinjauan Konsep Islam Radikal Yusuf Qardhawi." Ijtimaiyya: Jurnal Pengembangan Masyarakat Islam 13, no. 1 (11 Juli 2020): 103-16. https://doi.org/10.24042/ijpmi.v13i1.5808.

Hakim, Atang Abd, dan Jaih Mubarok. Metodologi Studi Islam. Bandung, Indonesia: Remaja Rosdakarya, 2012.

Hasbullah, Ali. Ușul at-Tashri' 'l-Islâmî. Kairo: Dar al-Ma'arif, 1976.

Khalaf, Abdul Wahab. Khulâșah at-Tashrì' 'l-Islâmî. Kuwait: Dar al-Qalam, t.t.

Kistoro, Hanif, Badrun Kartowagiran, Eva Latipah, Ngainun Naim, Himawan Putranta, dan Darmanto Minggele. "Islamophobia in education: perceptions on the use of veil/niqab in higher education." Indonesian Journal of Islam and Muslim Societies 10, no. 2 (21 Desember 2020): 227-46. https://doi.org/10.18326/ijims.v10i2.227-246.

Korangy, Alireza, Wheeler M. Thackston, Roy P. Mottahedeh, dan William Granara. Essays in Islamic Philology, History, and Philosophy. Walter de Gruyter GmbH \& Co KG, 2016.

Musa, Muhammad Yusuf. at-Tashrì" '-Islâmî wa Atharuh fì "l-Fiqh '-Gharbî. Beirut: al-Ashr alHadits, 1991.

Nasution, Harun. Islam Ditinjau dari Berbagai Aspeknya. Jilid II: ... Cet. 6. Jakarta: Penerbit Universitas Indonesia, 1986.

Nata, Abuddin. Metodologi Studi Islam. Jakarta: RajaGrafindo Persada, 2008.

Piela, Anna. "How Do Muslim Women Who Wear the Niqab Interact with Others Online? A Case Study of a Profile on a Photo-Sharing Website." New Media \& Society 19, no. 1 (1 Januari 2017): 67-80. https://doi.org/10.1177/1461444816649919.

Rasyid, Lisa Aisiyah, dan Rosdalina Bukido. "Problemtika Hukum Cadar Dalamislam: Sebuah Tinjauan Normatif-Historis.” Jurnal Ilmiah Al-Syir'ab 16, no. 1 (1 Agustus 2018): 74-92. https://doi.org/10.30984/jis.v16i1.648.

Rohimat, Asep Maulana. Metodologi Studi Islam: Memahami Islam Rahmatan Lil'alamin. Yogyakarta: Gerbang Media Aksara, 2018.

Sartika, Vivi, dan M. Yusuf. “'Bercadar Itu Pengakuan'; Reproduksi Makna Cadar di Kalangan Pengguna." Indonesian Journal of Religion and Society 2, no. 2 (18 Desember 2020): 87-96. https://doi.org/10.36256/ijrs.v2i2.107. 
Shaltut, Mahmud. al-Islâm Aqîdat wa Sharîat. Kairo: Dar al-Syuruq, 2001.

Shihab, M. Quraish. "Membumikan Al-Quran." Bandung: Mizan, 1992. http://saifbintoro.mywapblog.com/files/membumikan-al-quran.pdf.

Shirazi, Faegheh, dan Smeeta Mishra. "Young Muslim Women on the Face Veil (Niqab): A Tool of Resistance in Europe but Rejected in the United States." International Journal of Cultural Studies 13, no. 1 (1 Januari 2010): 43-62. https://doi.org/10.1177/1367877909348538.

Sudirman, Muh. "Cadar Bagi Wanita Muslimah dalam Perspektif Hukum Islam” 4 (2018): 9.

Syeikh, Abdul Karim. "Pemakaian Cadar dalam Perspektif Mufassirin dan Fuqaha" 16, no. 1 (2019): 16.

Ulumuddin, Imam Khoirul. "Niqab (Cadar) Dalam Perspektif Hukum Islam," t.t., 19.

Zakzouk, Mahmoud. an-Niqâb Âdat wa Laisa Ibâdat: ar-Ra'y ash-Shar'î fî an-Niqâb bi Aqlâm Kibâr 'l-Ulamâ. Kairo: Wazarah al-Auqaf al-Mishriyah, 2008.

Zempi, Irene. "'It's a part of me, I feel naked without it': choice, agency and identity for Muslim women who wear the niqab." Ethnic and Racial Studies 39, no. 10 (8 Agustus 2016): 1738-54. https://doi.org/10.1080/01419870.2016.1159710.

. "Veiled Muslim women's views on law banning the wearing of the niqab (face veil) in public." Ethnic and Racial Studies 42, no. 15 (18 November 2019): 2585-2602. https://doi.org/10.1080/01419870.2019.1588985. 